\title{
Seasonal and interannual ice velocity changes of Polar Record Glacier, East Antarctica
}

\author{
Chunxia ZHOU, ${ }^{1}$ Yu ZHOU, ${ }^{1,2}$ Fanghui DENG, ${ }^{1}$ Songtao AI, ${ }^{1}$ Zemin WANG, ${ }^{1}$ \\ Dongchen $\mathrm{E}^{1}$ \\ ${ }^{1}$ Chinese Antarctic Center of Surveying and Mapping, Wuhan University, Wuhan, China \\ E-mail: zhoucx@whu.edu.cn \\ ${ }^{2}$ Department of Earth Sciences, University of Oxford, Oxford, UK
}

\begin{abstract}
We present a study of seasonal and interannual ice velocity changes at Polar Record Glacier, East Antarctica, using ERS-1/2, Envisat and PALSAR data with D-InSAR and intensity tracking. Ice flow showed seasonal variations at the front of the glacier tongue. Velocities in winter were $19 \%$ less than velocities during summer. No significant interannual changes were detected. Ice velocities in the grounding zone and grounded glacier did not show clear seasonal or interannual changes. The distribution of the seasonal variations suggests that the cause for the changes should be localized. Possible causes are seasonal sea-ice changes and iceberg blocking. Satellite images show that the sea ice surrounding Polar Record Glacier undergoes seasonal changes. Frozen sea ice in winter slowed the huge iceberg, and provided increased resistance to the glacier flow. The interaction between the glacier tongue, iceberg and sea ice significantly influences their flow pattern.
\end{abstract}

KEYWORDS: Antarctic glaciology, glacier flow, glacier fluctuations, ice velocity, remote sensing

\section{INTRODUCTION}

Ice velocity measurements of the Antarctic ice sheet indicate how ice is transported from the interior of the continent to the oceans (Rignot and others, 2011). Estimation of ice velocities has been widely studied using remote-sensing data, particularly synthetic aperture radar (SAR) data (Kwok and Fahnestock, 1996; Joughin and others, 1998; Michel and Rignot, 1999; Rignot and Kanagaratnam, 2006; Liu and others, 2007; Rignot and others, 2011). Rignot and others (2011) presented the first complete, high-resolution, digital mosaic of ice motion in Antarctica, bringing new insights into ice-sheet dynamics. However, it is still unclear how the glaciers and ice sheets are responding to recent changes in climate.

Ice velocity changes of the Antarctic ice sheet impact both ice-sheet mass balances and sea-level changes (Rignot and others, 2003; Nicholls and Cazenave, 2010). Several fast-moving Antarctic ice streams and outlet glaciers (e.g. Pine Island Glacier) have been observed to have sped up between 1996 and 2007, leading to larger ice mass loss and sea-level rise (Rignot and others, 2002; Joughin and others, 2003; Rabus and Lang, 2003; Rignot, 2008). Scambos and others (2004) observed seasonal velocity variations in the Larsen B embayment and suggested that both summer melt percolation and changes in the stress field due to shelf removal play a major role in the glacier dynamics. Seasonal variations in ice velocity have also been detected at Shirase Glacier, $150 \mathrm{~km}$ south of the Japanese Syowa station, where ice velocity is $>1000 \mathrm{ma}^{-1}$ (Pattyn and Derauw, 2002; Nakamura and others, 2007, 2010). Further research concerning ice velocity changes has been carried out in Greenland (Zwally and others, 2002; Bingham and others, 2003; Joughin and others, 2008; Strozzi and others, 2008).

Outlet glaciers often respond more rapidly to local effects of global climate changes than inland glaciers (Scambos and others, 2004). In this paper, we present a study of ice velocity changes for a small outlet glacier in East Antarctica, using a combination of interferometric and intensity tracking methods. The capability of the interferometric method for precise ice-flow mapping has been demonstrated in many previous studies (Goldstein and others, 1993; Hartl and others, 1994; Joughin and others, 1995), while the intensity tracking method can estimate the velocity of fast-moving outlet glaciers with an accuracy of $\sim 20 \mathrm{~m} \mathrm{a}^{-1}$ (Gray and others, 2001; Joughin, 2002; Strozzi and others, 2002; Sundal and others, 2011).

\section{STUDY AREA}

Polar Record Glacier is located in the Prydz Bay area on the eastern side of the Amery Ice Shelf (Fig. 1). It is the largest outlet glacier along the Ingrid Christensen Coast, bounded by Meknattane Nunataks and Dodd Island. The Chinese Zhongshan station is located to the east, $50 \mathrm{~km}$ from the glacier. Comparison between Multispectral Scanner (MSS) and Thematic Mapper (TM) images (Fig. 2) shows that an enormous piece of ice, about $26 \mathrm{~km}$ long and $16 \mathrm{~km}$ wide, broke away from the glacier between 1973 and 1989 (however, more evidence is needed to confirm the exact time at which this calving occurred). The iceberg had a surface area of $>450 \mathrm{~km}^{2}$ when it first calved from the glacier tongue. The area is now $<300 \mathrm{~km}^{2}$ after several subsequent calving events. The traces of the ice streams can be identified with the satellite images.

\section{METHODOLOGY}

Interferometric and intensity tracking methods based on SAR data are widely used for measuring ice motion in Antarctica. The interferometric method, known as differential synthetic aperture radar interferometry (D-InSAR), uses the phase difference between two signals to calculate the surface topography and coherent displacements along the radar line of sight (LOS). The motion field can be precisely derived after the topographic contribution to the interferometric 


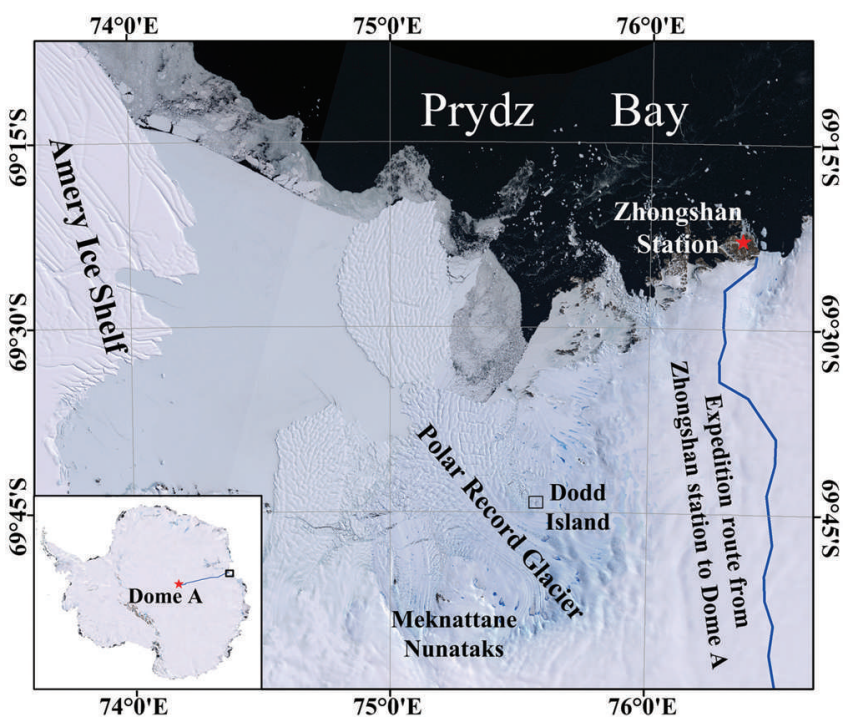

Fig. 1. Polar Record Glacier near the Chinese Zhongshan station in East Antarctica. Base map is a Landsat image. Polar Record Glacier is the largest outlet glacier along the Ingrid Christensen Coast, bounded by Meknattane Nunataks and Dodd Island. The blue line indicates China's inland expedition route from Zhongshan station to Dome A.

phase is correctly removed. However, this method is sometimes limited by the lack of an accurate digital elevation model (DEM) as well as loss of signal coherence caused by fast ice motion and weathering in some areas (Hanssen, 2001; Rignot and others, 2008). Intensity tracking is a welcome complement to D-InSAR for the measurement of ice velocity since it can estimate displacements in both range and azimuth directions, though with lower resolution and less accuracy. For the intensity tracking method, we use the location of the peak of the two-dimensional crosscorrelation function between two SAR images to determine the offsets between matching points (Strozzi and others, 2008). The derived offset field comprises an orbital plane and surface displacements between the two acquisitions. The orbital plane is determined by fitting a bilinear polynomial function through non-moving areas and removed from the offset field to obtain absolute ice motion.
The intensity tracking method is more robust in the case of low coherence and a lack of accurate DEMs, because the measurements depend on the presence of nearly identical intensity features in the two SAR acquisitions.

We applied D-InSAR to Polar Record Glacier based on one European Remote-sensing Satellite (ERS-1/2) tandem pair with very short perpendicular baseline length $(\sim 21 \mathrm{~m})$ in order to minimize both the loss of coherence and the influence of topographic errors. Four more pairs of SAR data from 2006 to 2008, including Envisat and Phased Array-type L-band SAR (PALSAR), were used to calculate ice velocity with intensity tracking. For Envisat data, we used averaging boxes of 128 (range) $\times 256$ (azimuth) samples in size, with a grid spacing of $12 \times 60$ samples. For PALSAR data, we used averaging boxes of $128 \times 128$ samples, with a grid spacing of $32 \times 64$ samples.

\section{RESULTS}

Although ice velocity for some parts is $>2 \mathrm{~m} \mathrm{~d}^{-1}$, the ERS-1/2 tandem pair is still highly coherent (Fig. 3a). The error of the D-InSAR result was exaggerated when calculating annual velocity based on the 1 day measurements. Only LOS displacements can be precisely obtained with D-InSAR. These can be projected to surface motion using a conversion model (Mattar and others, 1998), but the accuracy largely depends on the a priori flow direction. In this study, we used the flow direction from PALSAR data to derive the surface ice velocity. PALSAR data with a 46 day interval (Fig. $3 \mathrm{~b}$ and c) work well in most areas which are radar bright. Envisat data (Fig. 3d and e) only work for the glacier tongue. PALSAR data are better than Envisat C-band data at measuring velocities of outlet glaciers because the higher penetration ability of the L-band data can better overcome surface decorrelation (Rignot and others, 2001).

The estimated velocities were compared with large samples of data over areas of static rocks present within each image. The root-mean-square errors (RMSE) for image pairs 19960524/19960525, 20060128/20060304, $20070217 / 20070324,20060603 / 20060719$ and $20071117 / 20080102$ are $0.1 \mathrm{~m} \mathrm{~d}^{-1}, 1.9 \mathrm{~m}(35 \text { days })^{-1}$, $2.7 \mathrm{~m}\left(35\right.$ days $^{-1}, 0.6 \mathrm{~m}(46 \text { days })^{-1}$ and $1.8 \mathrm{~m}\left(46\right.$ days $^{-1}$ respectively (i.e. $36.5,19.8,28.2,4.8$ and $14.3 \mathrm{ma}^{-1}$
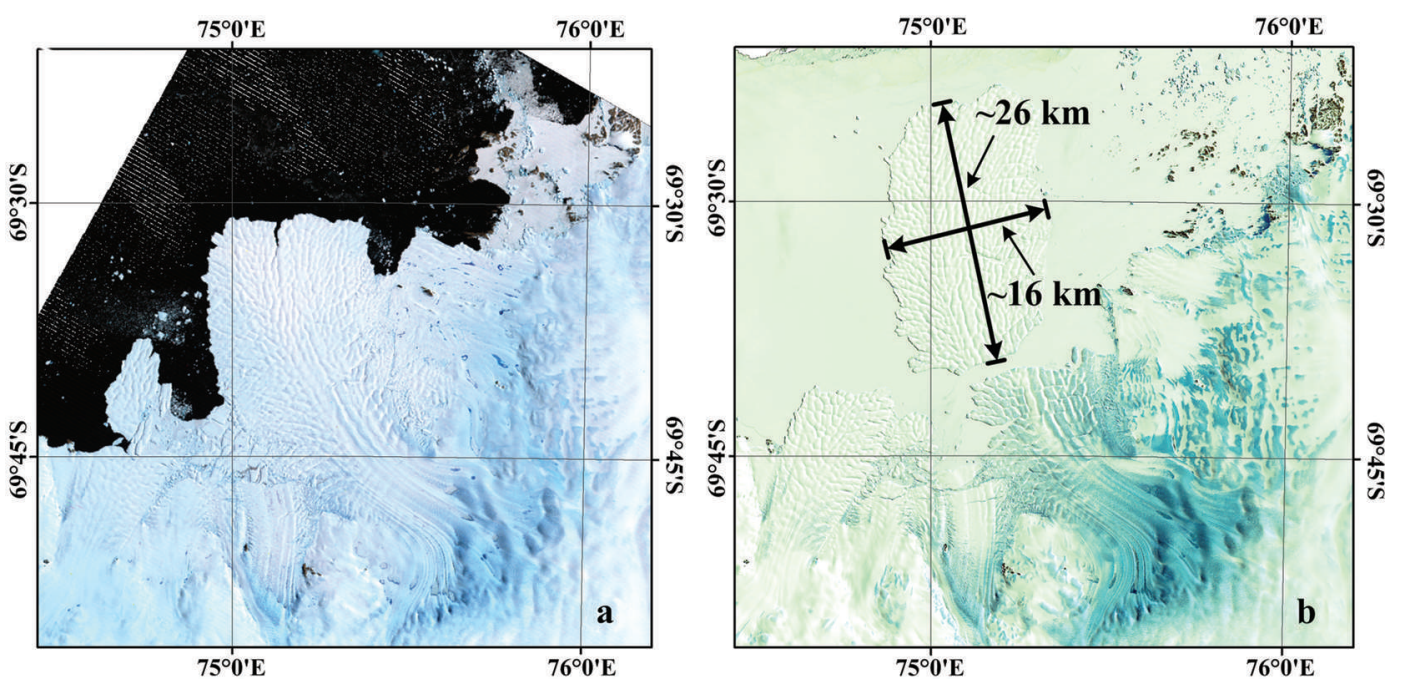

Fig. 2. Polar Record Glacier and calved iceberg. (a) MSS image collected on 4 February 1973; and (b) TM image collected on 24 December 1989. The iceberg, $\sim 26 \mathrm{~km}$ long and $16 \mathrm{~km}$ wide, calved from the glacier tongue between 1973 and 1989. 


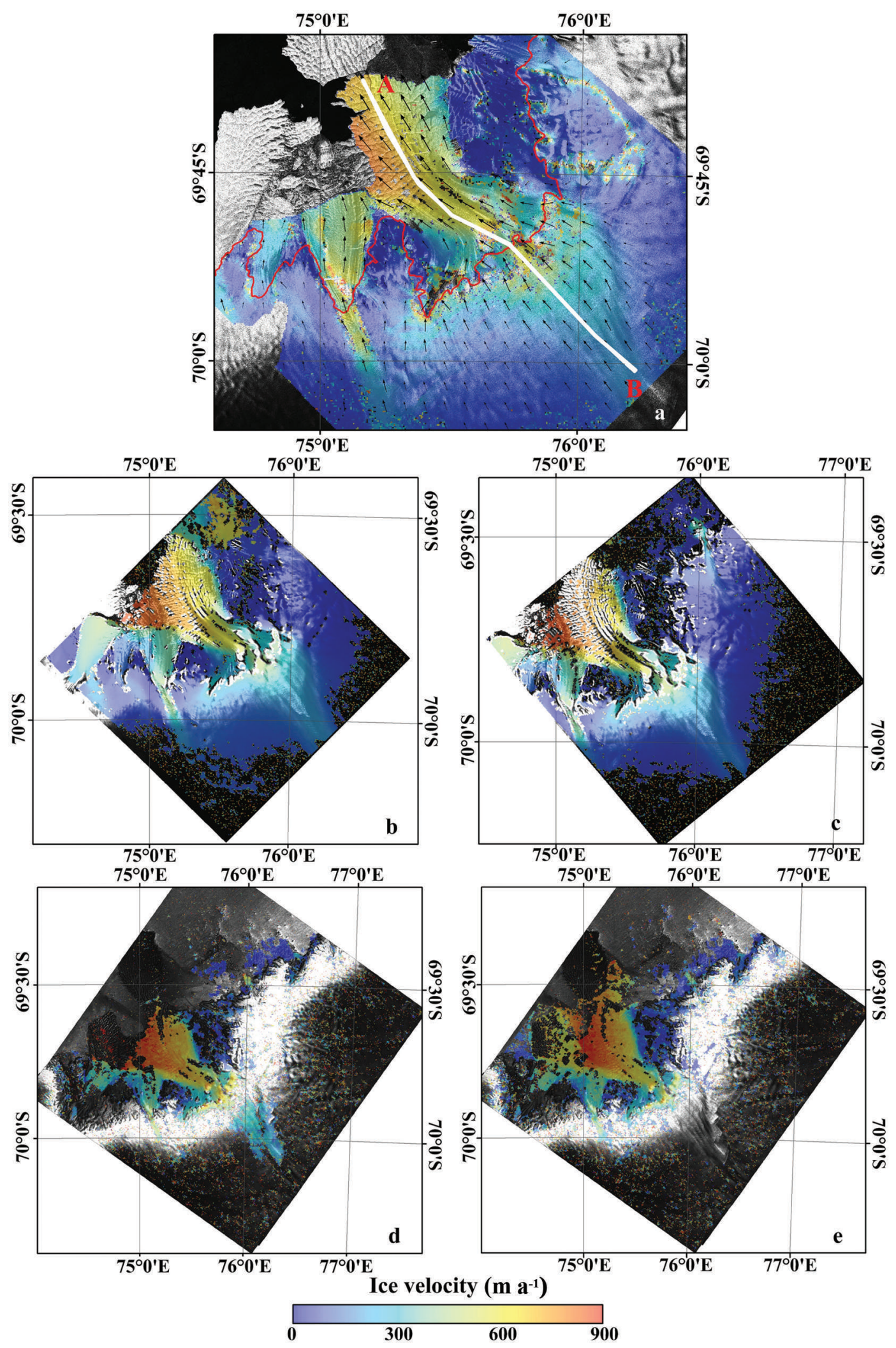

Fig. 3. Ice-flow maps derived from ERS-1/2 tandem data ((a) 19960524/19960525), PALSAR data ((b) 20060603/20060719 and (c) 20071117/ 20080102) and Envisat data ((d) 20060128/20060304 and (e) 20070217/20070324). The velocity field for Polar Record Glacier (a) was calculated based on the conversion model. Red line in (a) indicates the grounding line derived from Moderate Resolution Imaging Spectroradiometer (MODIS) Mosaic of Antarctica (Scambos and others, 2007). The estimated velocities were compared with large samples of data over areas of static rocks present within each image. The RMSE are (a) $36.5 \mathrm{~m} \mathrm{a}^{-1}$, (b) $19.8 \mathrm{~m} \mathrm{a}^{-1}$, (c) $28.2 \mathrm{~m} \mathrm{a}^{-1}$, (d) $4.8 \mathrm{~m} \mathrm{a}^{-1}$ and (e) $14.3 \mathrm{~m} \mathrm{a}^{-1}$.

respectively). The accuracy of the results from PALSAR data is much higher than that from Envisat data due to the higher resolution of PALSAR images (i.e. $7.5 \mathrm{~m}$ and $4.1 \mathrm{~m}$ in slantrange and azimuth directions respectively).
The ice velocity of Polar Record Glacier increases rapidly seaward, from $\sim 200 \mathrm{~m} \mathrm{a}^{-1}$ in inland areas to $>700 \mathrm{~m} \mathrm{a}^{-1}$ at the front of the glacier tongue. The western portion moves faster than the eastern portion. Polar Record Glacier, 


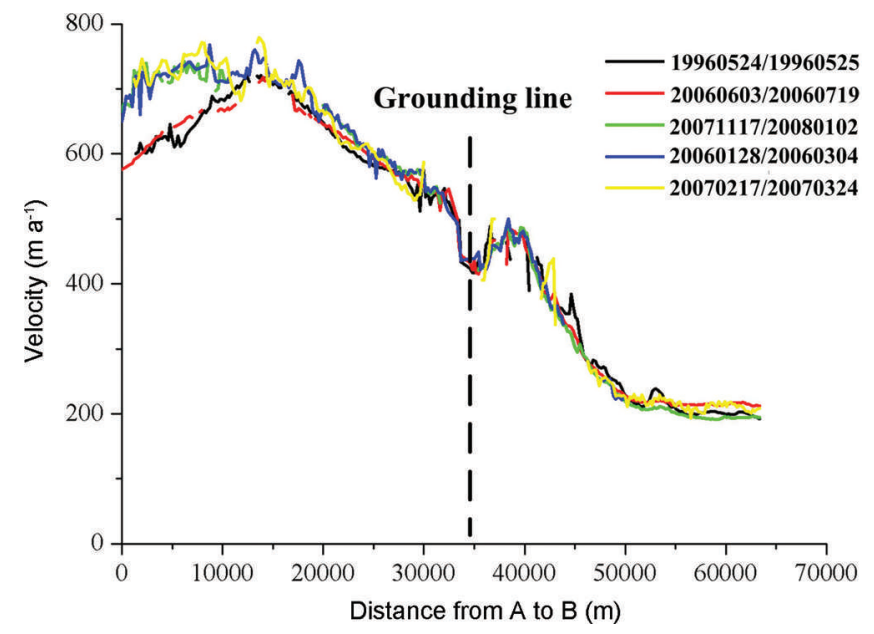

Fig. 4. Ice velocity profiles for Polar Record Glacier (A-B in Fig. 3a). Ice velocity increases rapidly seaward, from $\sim 200 \mathrm{~m} \mathrm{a}^{-1}$ in inland areas to $>700 \mathrm{~m} \mathrm{a}^{-1}$ at the front of the glacier tongue. The glacier tongue slowed by $19 \%$ (i.e. $140 \mathrm{ma}^{-1}$ ) from $720 \mathrm{ma}^{-1}$ in the summer to $580 \mathrm{~m} \mathrm{a}^{-1}$ in the winter. The estimated winter velocities in 1996 and 2007, and summer velocities in 2006-08, are consistent within the range of the corresponding errors.

together with several smaller ice streams nearby, dominates ice outflow from the inland area. In the grounding zone and grounded part of the glacier, we detect no change in seasonal or interannual velocity (Fig. 4). In contrast, icevelocity changes at the front of the glacier tongue (near A) are clear. The glacier tongue slowed by $19 \%$ (i.e. $140 \mathrm{~m} \mathrm{a}^{-1}$ ) from $720 \mathrm{~m} \mathrm{a}^{-1}$ in the summer to $580 \mathrm{~m} \mathrm{a}^{-1}$ in the winter. The estimated winter velocities in 1996 and 2007, and summer velocities in 2006-08, are consistent within the range of the corresponding errors. We therefore suggest that there is no evident interannual velocity change at Polar Record Glacier in 1996-2008. The ERS and Envisat results are in good agreement with the PALSAR results. The good agreement between the individual datasets and sensor systems points to the validity of the method used.

Based on the velocity fields, we generated detailed maps of velocity variations in time and space to further analyze the pattern of the changes (Fig. 5). Considering that the Envisat results did not cover much of the grounded ice, we used the PALSAR and ERS-1/2 results to calculate the maps of velocity difference. There were no evident velocity changes for the grounded ice between 1996 and 2008. Speed-up of the front of the glacier tongue in summer is clear, while winter velocities are consistent within the range of errors. However, we did not observe a similar pattern of seasonal changes in the vicinity of the glacier.

\section{DISCUSSION}

We observed seasonal velocity changes at the tongue of Polar Record Glacier between 1996 and 2008. Velocity varies less in the grounding zone and grounded part. The glacier tongue slowed by $19 \%$ during winter. The change extends $\sim 15 \mathrm{~km}$ from the glacier terminus. The grounding line is located $\sim 20 \mathrm{~km}$ further inland. It has been suggested that several factors (e.g. ice melting, air-temperature differences, stiffness of sea ice, interactions between air, sea ice and glacier flow) may cause seasonal variations in velocity during summer without causing annual velocity variations (Nakamura and others, 2007; Van de Wal and others, 2008; Bartholomew and others, 2010). At Polar Record Glacier, only the freefloating glacier tongue shows seasonal variations, indicating the force that slows the glacier tongue should be localized. The most likely explanation for this distribution of seasonal velocity changes is that the sea ice surrounding the glacier undergoes significant seasonal changes.

Different satellite images (optical and SAR images; Fig. 6) were collected to study sea-ice extent. Sea ice presents different characteristics in optical and SAR images. It is easy

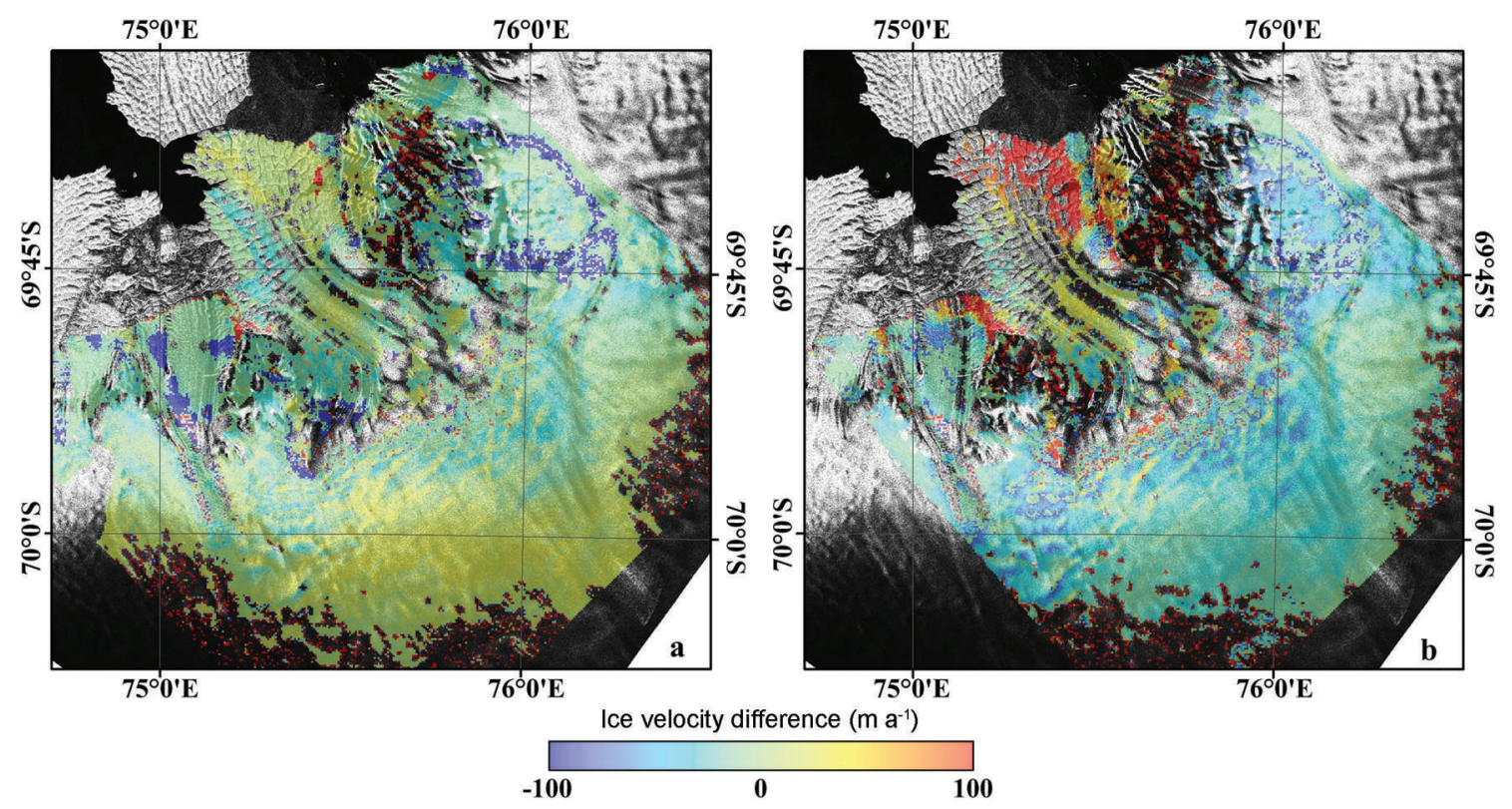

Fig. 5. Maps of velocity variations. (a) PALSAR result (20060603/20060719) minus ERS-1/2 tandem result (19960524/19960525); and (b) PALSAR result (20071117/20080102) minus ERS-1/2 tandem result (19960524/19960525). There were small to no velocity changes for the grounded ice between 1996 and 2008. Speed-up of the glacier tongue in summer is clear. Winter velocities are consistent within an error of $\sim 17 \mathrm{~m} \mathrm{a}^{-1}$. However, we did not observe a similar pattern of seasonal changes in the vicinity of the glacier. 

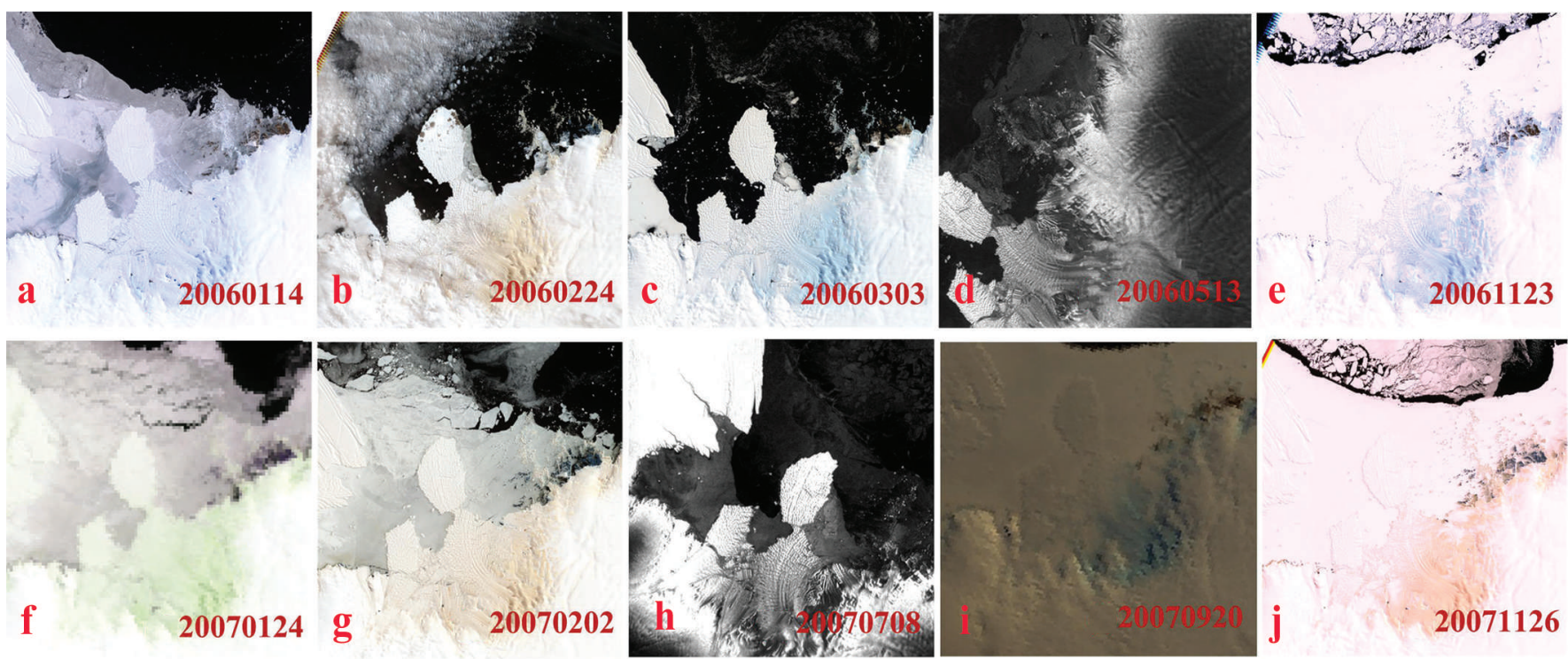

Fig. 6. Changes of sea-ice coverage surrounding Polar Record Glacier. $(\mathrm{a}-\mathrm{c}),(\mathrm{e}),(\mathrm{g})$ and $(\mathrm{j})$ are Landsat images, (d) and (h) are Envisat images, and ( $\mathrm{f}$ ) and (i) are MODIS data. In optical images, bright areas are sea ice and dark areas indicate ice-free water. In SAR images, brighter areas usually indicate thicker sea ice while dark areas indicate newer smooth sea ice (as in (d) and (h)).

to separate sea ice and sea water in optical images such as Landsat (e.g. Fig. 6a) and the Moderate Resolution Imaging Spectroradiometer (MODIS; Fig. 6f), with bright areas being sea ice and dark areas being ice-free water. For SAR images, brighter areas usually indicate thicker sea ice, while dark areas indicate newer smooth sea ice (Fig. 6h; Shuchman and Flett, 2004). As shown in Figure 6, sea-ice coverage surrounding the glacier changes with time. Sea-ice concentration depends on temperature, salinity of the ocean, etc. (Gordon, 1981). Therefore, even in the same month, seaice conditions may vary from year to year. In February 2006, sea ice disappeared, while in 2007 we can still see thin ice surrounding the glacier. But in general, sea ice in our study area started to break into small fragments in November. In January, the melting sea ice was thin and became thinner or disappeared in the following months. As temperature decreased, sea ice began to form and grow. Frozen sea ice slowed the huge iceberg, and provided increased resistance to the glacier flow. This is the pattern for seasonal sea-ice changes surrounding Polar Record Glacier.

During summer, an ice-free environment provides less resistance to the motion of the glacier. Winter sea ice provides increased resistance to the ice flow, causing the ice to slow down. Sea-ice change acts on not only the floating glacier tongue, but also the iceberg, which will in turn influence the motion of the glacier tongue. The interaction between the glacier terminus and iceberg further hampers the movement of the glacier tongue. By checking filled gaps between the glacier terminus and iceberg (Fig. 7), we found that the glacier tongue could have moved faster without the iceberg blocking the way. When the iceberg first calved from the glacier tongue, it underwent a transient period of acceleration, resulting in a $\sim 1.8 \mathrm{~km}$ gap between the iceberg and the glacier terminus (Fig. 7a). The iceberg then slowed and the glacier tongue caught up with the iceberg. In 1993, the glacier tongue and iceberg collided (Fig. 7b). After the collision, the iceberg sped up while the glacier tongue slowed down. We observed another $\sim 600 \mathrm{~m}$ gap due to the calving of the glacier terminus in 2003 (Fig. 7c). This gap was gradually filled by the fast-moving glacier tongue
(Fig. 7e). When the iceberg was slowed by surrounding winter sea ice, the velocity of the glacier tongue further decreased. Due to the limited data, it is hard to determine the exact time of the collisions and quantify the velocity change associated with the collisions.

\section{CONCLUSION}

D-InSAR and intensity tracking provide useful measurements of glacier motion in Antarctica. In this study, we have combined the two methods to investigate seasonal and interannual velocity changes of an outlet glacier in East Antarctica. Polar Record Glacier did not show clear interannual velocity changes in 1996-2008, but seasonal variations between summer and winter were observed at the glacier tongue. Velocity decreased $19 \%$ in winter, probably because of seasonal sea-ice changes and iceberg blocking. Winter sea ice blocks the iceberg, hampering the flow of the glacier tongue. By checking different satellite images, we found that the interaction between the glacier terminus and iceberg influences their flow pattern. The filled gap between the huge iceberg and glacier terminus suggests that the glacier tongue is being slowed by the huge iceberg in front of it. However, due to the limited data, we are unable to quantify the influence of the interaction on the flow pattern at present. Further investigation is needed to confirm and further explain this process and its impact on overall outlet glacier stability.

\section{ACKNOWLEDGEMENTS}

This research is funded by the National Nature Science Foundation of China (NSFC) (No. 41076126, No. 41376187), the Chinese 863 Program (No. 2009AA12Z133) and the Open Research Foundation of SOA Key Laboratory for Polar Sciences (No. KP201001). We thank the European Space Agency for providing data through the IPY (International Polar Year) announcement of opportunity (project ID 3685), the China Centre for Resources Satellite Data and Applications (CRESDA) for providing Huan-Jing-1A (HJ-1A) 

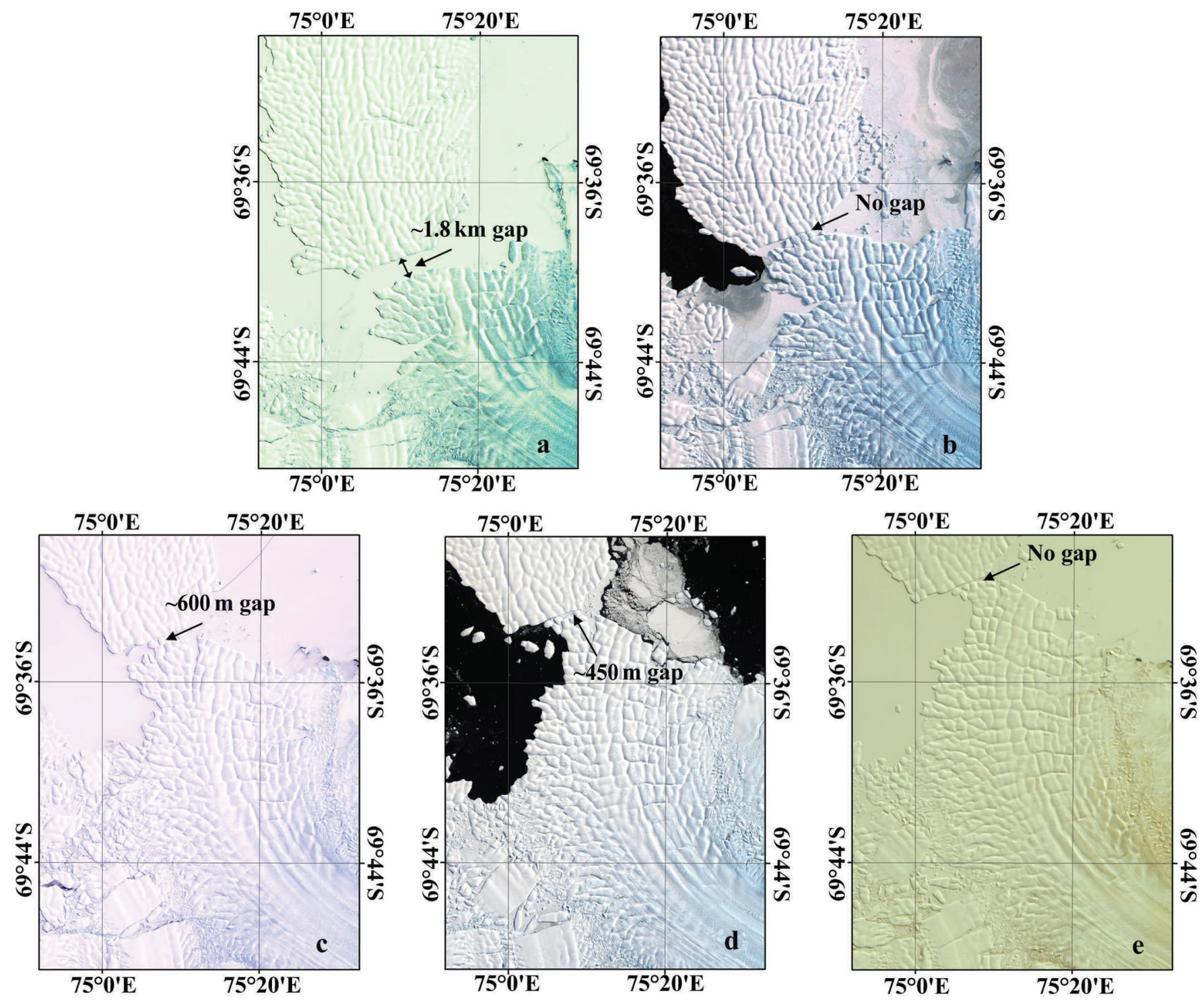

Fig. 7. Relative position of the glacier tongue and iceberg on (a) 19891124 (TM), (b) 19930331 (TM), (c) 20030106 (Enhanced TM Plus $($ ETM+)), (d) $20060303($ ETM+) and (e) 20091025 (HJ-1A). When the iceberg first calved from the glacier tongue, it underwent a transient period of acceleration, resulting in a $\sim 1.8 \mathrm{~km}$ gap between the iceberg and the glacier terminus (a). After the acceleration period, the iceberg slowed and the glacier tongue caught up with the iceberg. In 1993, the glacier tongue and iceberg collided (b). After the collision, the iceberg sped up while the glacier tongue slowed down. Another $\sim 600 \mathrm{~m}$ gap was observed in 2003 (c). This gap was gradually filled by the fast-moving glacier tongue (e).

data, and the Japanese National Institute of Polar Research for providing the PALSAR data. We also thank two anonymous reviewers and the editor for constructive comments and suggestions.

\section{REFERENCES}

Bartholomew I, Nienow P, Mair D, Hubbard A, King MA and Sole A (2010) Seasonal evolution of subglacial drainage and acceleration in a Greenland outlet glacier. Nature Geosci., 3(6), 408411 (doi: 10.1038/ngeo863)

Bingham RG, Nienow PW and Sharp MJ (2003) Intra-annual and intra-seasonal flow dynamics of a High Arctic polythermal valley glacier. Ann. Glaciol., 37, 181-188 (doi: 10.3189/ 172756403781815762)

Goldstein RM, Engelhardt H, Kamb B and Frolich RM (1993) Satellite radar interferometry for monitoring ice sheet motion: application to an Antarctic ice stream. Science, 262(5139), 1525-1530 (doi: 10.1126/science.262.5139.1525)
Gordon AL (1981) Seasonality of Southern Ocean sea ice. J. Geophys. Res., 86(C5), 4193-4197 (doi: 10.1029/ JC086iC05p04193)

Gray L, Short N, Mattar KE and Jezek KC (2001) Velocities and flux of the Filchner Ice Shelf and its tributaries determined from speckle tracking interferometry. Can. J. Remote Sens., 27(3), 193-206

Hanssen RF (2001) Radar interferometry: data interpretation and error analysis. Kluwer Academic Publishers, Dordrecht

Hartl P, Thiel KH, Wu X, Doake CSM and Sievers J (1994) Application of SAR interferometry with ERS-1 in the Antarctic. Earth Obs. Q., 43, 1-4

Joughin I (2002) Ice-sheet velocity mapping: a combined interferometric and speckle-tracking approach. Ann. Glaciol., 34, 195-201

Joughin IR, Winebrenner DP and Fahnestock MA (1995) Observations of ice-sheet motion in Greenland using satellite radar interferometry. Geophys. Res. Lett., 22(5), 571-574 (doi: 10.1029/95GLO0264)

Joughin IR, Kwok R and Fahnestock MA (1998) Interferometric estimation of three-dimensional ice-flow using ascending and 
descending passes. IEEE Trans. Geosci. Remote Sens., 36(1), 25-37 (doi: 10.1109/36.655315)

Joughin I, Rignot E, Rosanova CE, Lucchitta BK and Bohlander J (2003) Timing of recent accelerations of Pine Island Glacier, Antarctica. Geophys. Res. Lett., 30(13), 1706 (doi: 10.1029/ 2003GL017609)

Joughin I, Das SB, King MA, Smith BE, Howat IM and Moon T (2008) Seasonal speedup along the western flank of the Greenland Ice Sheet. Science, 320(5877), 781-783 (doi: 10.1126/science.1153288)

Kwok R and Fahnestock MA (1996) Ice sheet motion and topography from radar interferometry. IEEE Trans. Geosci. Remote Sens., 34(1), 189-200 (doi: 10.1109/36.481903)

Liu H, Zhao Z and Jezek KC (2007) Synergistic fusion of interferometric and speckle-tracking methods for deriving surface velocity from interferometric SAR data. IEEE Trans. Geosci. Remote Sens., 4(1), 102-106 (doi: 10.1109/LGRS.2006.885885)

Mattar KE, Vachon PW, Geudtner D, Gray AL, Cumming IG and Brugman M (1998) Validation of alpine glacier velocity measurements using ERS tandem-mission SAR data. IEEE Trans. Geosci. Remote Sens., 36(3), 974-984 (doi: 10.1109/ 36.673688)

Michel R and Rignot E (1999) Flow of Glaciar Moreno, Argentina, from repeat-pass Shuttle Imaging Radar images: comparison of the phase correlation method with radar interferometry. J. Glaciol., 45(149), 93-100

Nakamura K, Doi K and Shibuya K (2007) Estimation of seasonal changes in the flow of Shirase Glacier using JERS-1/SAR image correlation. Polar Sci., 1(2-4), 73-83 (doi: 10.1016/j.polar. 2007.09.002)

Nakamura K, Doi K and Shibuya K (2010) Fluctuations in the flow velocity of the Antarctic Shirase Glacier over an 11-year period. Polar Sci., 4(3), 443-455 (doi: 10.1016/j.polar.2010.04.010)

Nicholls RJ and Cazenave A (2010) Sea-level rise and its impact on coastal zones. Science, 328(5985), 1517-1520 (doi: 10.1126/ science.1185782)

Pattyn F and Derauw D (2002) Ice-dynamic conditions of Shirase Glacier, Antarctica, inferred from ERS SAR interferometry. J. Glaciol., 48(163), 559-565 (doi: 10.3189/ 172756502781831115)

Rabus BT and Lang O (2003) Interannual surface velocity variations of Pine Island Glacier, West Antarctica. Ann. Glaciol., 36, 205-214 (doi: 10.3189/172756403781816239)

Rignot E (2008) Changes in West Antarctic ice stream dynamics observed with ALOS PALSAR data. Geophys. Res. Lett., 35(12), L12505 (doi: 10.1029/2008GL033365)

Rignot E and Kanagaratnam P (2006) Changes in the velocity structure of the Greenland Ice Sheet. Science, 311(5673), 986-990 (doi: 10.1126/science.1121381)
Rignot E, Echelmeyer K and Krabill W (2001) Penetration depth of interferometric synthetic-aperture radar signals in snow and ice. Geophys. Res. Lett., 28(18), 3501-3504 (doi: 10.1029/ 2000GL012484)

Rignot E, Vaughan DG, Schmeltz M, Dupont T and MacAyeal D (2002) Acceleration of Pine Island and Thwaites Glaciers, West Antarctica. Ann. Glaciol., 34, 189-194 (doi: 10.3189/ 172756402781817950)

Rignot E, Rivera A and Casassa G (2003) Contribution of the Patagonian icefields of South America to sea level rise. Science, 302(5644), 434-437 (doi: 10.1126/science.1087393)

Rignot E, Mouginot J and Scheuchl B (2011) Ice flow of the Antarctic Ice Sheet. Science, 333(6048), 1427-1430 (doi: 10.1126/science.1208336)

Scambos TA, Bohlander JA, Shuman CA and Skvarca P (2004) Glacier acceleration and thinning after ice shelf collapse in the Larsen B embayment, Antarctica. Geophys. Res. Lett., 31(18), L18402 (doi: 10.1029/2004GL020670)

Scambos TA, Haran TM, Fahnestock MA, Painter TH and Bohlander J (2007) MODIS-based Mosaic of Antarctica (MOA) data sets: continent-wide surface morphology and snow grain size. Remote Sens. Environ., 111(2-3), 242-257 (doi: 10.1016/ j.rse.2006.12.020)

Shuchman RA and Flett DG (2004) SAR measurement of sea ice parameters: sea ice session overview paper. In Proceedings of the Second Workshop on Coastal and Marine Applications of SAR, 8-12 September 2003, Svalbard, Norway. (ESA SP-565) European Space Agency, Noordwijk, 151-160 http://earth. esa.int/workshops/cmasar_2003/papers/E16shuc.pdf

Strozzi T, Luckman A, Murray T, Wegmuller $\mathrm{U}$ and Werner $\mathrm{CL}$ (2002) Glacier motion estimation using satellite-radar offsettracking procedures. IEEE Trans. Geosci. Remote Sens., 40(11), 2834-2391 (doi: 10.1109/TGRS.2002.805079)

Strozzi T, Kouraev A, Wiesmann A, Wegmüller U, Sharov A and Werner C (2008) Estimation of Arctic glacier motion with satellite L-band SAR data. Remote Sens. Environ., 112(3), 636-645 (doi: 10.1016/j.rse.2007.06.007)

Sundal AV, Shepherd A, Nienow P, Hanna E, Palmer S and Huybrechts P (2011) Melt-induced speed-up of Greenland ice sheet offset by efficient subglacial drainage. Nature, 469(7331), 521-524 (doi: 10.1038/nature09740)

Van de Wal RSW and 6 others (2008) Large and rapid melt-induced velocity changes in the ablation zone of the Greenland Ice Sheet. Science, 321(5885), 111-113 (doi: 10.1126/science. 1158540)

Zwally HJ, Abdalati W, Herring T, Larson K, Saba J and Steffen K (2002) Surface melt-induced acceleration of Greenland icesheet flow. Science, 297(5579), 218-222 (doi: 10.1126/ science.1072708) 